\title{
Wayang: How is it Used to Improve Children's Language Skills?
}

\author{
$1^{\text {st }}$ Santi Alfiyah \\ Early Childhood Teacher Education \\ Study Program \\ Universitas Muhammadiyah Sidoarjo \\ Indonesia \\ lina@umsida.ac.id
}

\author{
$2^{\text {nd }}$ Choirun Nisak Aulina \\ Early Childhood Teacher Education \\ Study Program \\ Universitas Muhammadiyah Sidoarjo \\ Indonesia
}

\author{
$3^{\text {rd }}$ Agus Salim \\ Early Childhood Teacher Education \\ Study Program \\ Universitas Muhammadiyah Sidoarjo \\ Indonesia
}

\begin{abstract}
Language skills are the ability to express something in mind through communication. The development of language skills in early childhood is significant because it is a provision for children to communicate with people around them. This study aims to determine the improvement of children's language skills through the method of storytelling using wayang. The research method used was classroom action research. The subjects of the study were the second year students of kindergarten in East Java, Indonesia. The participants were 17 children consisting of 5 males and 12 females. The data collection technique includes assessment sheets, observations, and documentation. The children's language skills are seen in terms of 1) Children are able to be good listeners, 2) children are able to participate in the conversation, children are able to do self-expression. The research was carried out in 2 cycles starting with pre-cycle activities, cycle one, and cycle 2 . The criteria of success set in this study are $75 \%$. In the first cycle, the percentage of children's language skills attainment is $\mathbf{5 3 \%}$. Therefore, the second cycle was carried out with some revision on the method. The result shows an increase in children's language skills since they could reach $88 \%$. This indicates that the purpose of storytelling using wayang can improve children's language skills.
\end{abstract}

Keywords—wayang, Chlidren, Language Skills

\section{INTRODUCTION}

Kindergarten is a form of early childhood education in the formal pathway that organizes educational programs for children aged four to six years. Kindergarten education plays an essential role in developing children's abilities to be ready to enter the next level of education. One aspect of development that is very important for children is language development. Chomsky states that every human being naturally possesses language skills. He said that children have a blueprint to be able to create their own mental structures spontaneously [1]. Children naturally grasp the system of language rules and begin to understand the sentences that are heard. When the child follows the rule system, at that time, the child is also able to create new sentences with the same rule system.

Language is a conventional symbol system to transfer various ideas and information consisting of visual and verbal symbols[2]. These visual symbols can be seen, written, and read, while verbal symbols can be heard and spoken. Children can communicate with their peers through language, using the language of children also get new experiences can also develop cognitive development. This ability is obtained by children when they hear other people talking.

Language is essential for humans to master because the intellectual development of a child is related to language. Language helps children to direct their thoughts, sharpen their memories, categorize, and learn new things so that their children's thinking is increasing [3]. Children communicate with other individuals using language; with language, children will add new things to what he hears through conversations with friends so that the child's ability will increase.

Language allows children to translate experiences into symbols that can be used to communicate and think [4]. In early childhood, language symbols that are often used are verbal symbols that are heard and spoken. The child will listen to what he hears or through conversation between friends; after that, the child is able to distinguish different sounds or sounds, the child can understand the contents and words. Language is very important for children to meet the needs in the environment; language is able to change and to control behaviour and behaviour as a social tool; language becomes a way of reacting to others. In language, children can increase cognitive growth [5]

Based on observations still found children's language skills in kindergartens who are still lacking in the ability to be a good listener, participate in the conversation, and in self-expression. This is because the teacher does not use media that are attractive to children, so the child feels bored and less interested in the teacher's story. The teacher does not ask children the question again to the child as recalling after telling the story, in telling the teacher the expression is lacking, so the child is not interested in the story. Children are less able to recall the story because the child does not enjoy the story, so told to repeat the story, the child is less capable. Then teachers should scaffold children's language during play by using research-based strategies such as asking questions that 
invite extended responses and new inquiry, providing meaningful feedback and effectively using wait time, which provides children with the opportunity to respond to adults' comments and questions [6].

Storytelling is an activity carried out by someone to convey a message, information, or a mere fairy tale, which can be done verbally or in writing, how the story can be told by using props or without props [7]. By using props that attract children will be interested in the contents of the story, the child will be focused on the teacher's mother telling the story, with the child listening to the story the child will store the storyline in his brain so that if the child is asked to understand the contents of the story being told, the child is also happy the heart will repeat the story even though the child's own language does not have to be exactly like the teacher's story. By telling stories, children can improve their language skills.

According to [8], storytelling is a storytelling activity. Storytelling is an activity related to telling a story to one or more listeners. Through storytelling will also make it easier for children to absorb the messages conveyed through the storytelling activity itself [9]. The method of storytelling is a way of communicating or transferring appropriate knowledge following early childhood development to produce maximum understanding for students. Every educator should use methods that are appropriate to the objectives of the characteristics of early childhood. The technique is a method or procedure adopted by educators in managing effective and efficient learning [4]. Storytelling is an activity that someone does verbally to others with tools or without tools about what should be conveyed in the form of messages, information, or just a fairy tale that is listened to with a pleasant sense [7]. The teaching aids used should be of interest to the child so that the child will be interested in trying it out. Namely by telling a story orally both by reading directly from a book or by using picture illustrations. Can also use props such as hand puppets or puppets.

As the principle of early childhood education, namely learning through real objects. So the need for the media as an aid to convey educational messages for early childhood [10] in addition to the use of media teachers must be selective with the media to be used because the media is highly correlated with age [11], so when telling stories to visualize the characters in the story, wayang can be used. Puppet can be an exciting learning media to be used to meet the visualization needs of children in receiving information in the story. From the results of Daboti's research, et al. stated that the wayang media is a media that helps children in obtaining ease when telling stories or playing the role of dialogue because with the help of puppets as props can improve children's skills in processing or developing story ideas that they will tell [12].

Wayang media are imitation dolls made from carved leather or wood or paper, which can be used to portray characters in drama shows [13]. So the puppet media is a tool used in the form of imitation dolls that resemble characters that will be portrayed to tell stories. The purpose of the puppet game is to provide knowledge and attitude of manners. The definition of a puppet is an imitation of people made from carved leather or wood that can be utilized to portray a character in a traditional drama performance, usually played by someone called a dalang. The puppet media used must be in accordance with the character or theme being played so that it can attract the attention of the child.

Wayang in this study are not traditional puppets made for village ruwat, or the spectacle of people who have a desire, but puppets for early childhood media in telling stories, so that children are interested in retelling stories told by the teacher, the picture used is also not pictures of puppet characters such as Semar, Petrok, Bagong and so on, but drawings according to the characters to be told such as pictures of elephants, ants, rabbits and so on.

\section{RESEARCH METHODS}

\section{A. Type of Research}

This type of research is descriptive qualitative using the Classroom Action Research research design. This research was conducted by looking at learning activities in the form of an action that was deliberately raised and occurred in a class together [14].

\section{B. Research Procedures}

The research phase refers to Kemmis and Mc. Taggart's theory that Classroom Action Research (CAR) has four steps, namely, planning, action, observation, and reflection [15]. Planning means making plans for actions to be taken to improve learning practices, in detail and clearly. This plan is based on the problem at hand. Action means planning. In general, this action takes the form of learning by using certain methods following planning, which, according to the researchers' assumptions, has benefits. Observation means an effort to obtain input or data regarding the results of actions taken. Reflection involves analyzing and interpreting the results of Classroom Action Research, and it is also possible to plan further steps to increase their shortcomings.

\section{Research Subjects}

The study was conducted in collaboration with class teachers. Subjects were children from group B kindergarten with 17 students consisting of 12 girls and five boys.

\section{Data collection and analysis techniques}

The data collection techniques using the method of observation, interviews, and documentation. Observations were made with reference to children's language ability instruments with a checklist method with rating ratings of 1 to 4 points. Interviews were conducted with class teachers and students to explore the effectiveness and response of students to the application of the method of storytelling using puppets.

Data analysis technique uses the calculation of the percentage increase with the formula:

$\mathrm{P}=\frac{f}{N} \times 100 \%$

a. $\mathrm{P}=$ percentage

b. $\mathrm{f}=$ the amount obtained

c. $\mathrm{n}=$ number of observation items [16] 
The target of success in this study is $75 \%$ achievement in increasing children's language skills by referring to three indicators, namely 1) Children can be good listeners, 2) Children can participate in a conversation, 3) Children can do self-expression

\section{RESULTS AND DISCUSSION}

Before this class action research was carried out, the problem found was that children's language skills had not yet reached the stage of age development. This can be seen from the related students who are less focused on the activities of the teacher telling stories when learning so that children are asked about the contents of the story the children do not understand it, also when told to repeat the story the poor children. When researchers carry out observations, researchers see the lack of media used by teachers when telling stories. Learning activities are more likely to use small picture books.

\begin{tabular}{|c|c|c|c|c|c|c|c|c|c|}
\hline \multirow[b]{2}{*}{ Subject } & \multicolumn{3}{|c|}{ Indicator Values 1} & \multicolumn{3}{|c|}{ Cycle Value 1 (Indicator) } & \multicolumn{3}{|c|}{ Cycle Values 2 (Indicator) } \\
\hline & $\begin{array}{c}\text { Pre- } \\
\text { cycle }\end{array}$ & $\begin{array}{c}\text { Cycle- } \\
1 \\
\end{array}$ & $\begin{array}{c}\text { Cycle- } \\
2 \\
\end{array}$ & $\begin{array}{l}\text { Pre- } \\
\text { cycle }\end{array}$ & Cycle- 1 & Cycle- 2 & $\begin{array}{l}\text { Pre- } \\
\text { cycle }\end{array}$ & Cycle- 1 & Cycle- 2 \\
\hline Subject 1 & 2 & 2 & 3 & 2 & 3 & 3 & 1 & 2 & 3 \\
\hline Subject 2 & 1 & 2 & 3 & 2 & 3 & 3 & 2 & 2 & 3 \\
\hline Subject 3 & 3 & 2 & 3 & 2 & 3 & 3 & 2 & 2 & 3 \\
\hline Subject 4 & 2 & 3 & 3 & 1 & 2 & 2 & 2 & 3 & 3 \\
\hline Subject 5 & 2 & 3 & 3 & 2 & 3 & 3 & 2 & 2 & 2 \\
\hline Subject 6 & 1 & 2 & 2 & 1 & 2 & 2 & 1 & 1 & 2 \\
\hline Subject 7 & 1 & 1 & 3 & 2 & 2 & 3 & 2 & 2 & 3 \\
\hline Subject 8 & 1 & 3 & 3 & 3 & 3 & 3 & 1 & 1 & 3 \\
\hline Subject 9 & 1 & 2 & 3 & 2 & 2 & 2 & 2 & 2 & 3 \\
\hline Subject 10 & 2 & 3 & 3 & 3 & 3 & 3 & 2 & 3 & 3 \\
\hline Subject 11 & 1 & 2 & 3 & 1 & 2 & 3 & 1 & 1 & 3 \\
\hline Subject 12 & 1 & 3 & 3 & 1 & 3 & 3 & 1 & 2 & 2 \\
\hline Subject 13 & 2 & 2 & 3 & 1 & 1 & 3 & 2 & 2 & 3 \\
\hline Subject 14 & 2 & 3 & 3 & 2 & 2 & 3 & 2 & 2 & 3 \\
\hline Subject 15 & 1 & 1 & 3 & 2 & 2 & 3 & 1 & 1 & 3 \\
\hline Subject 16 & 2 & 2 & 2 & 1 & 2 & 2 & 1 & 1 & 2 \\
\hline Subject 17 & 2 & 2 & 3 & 1 & 2 & 3 & 2 & 2 & 3 \\
\hline Average & 1.6 & 2.2 & 2.9 & 1.7 & 2.4 & 2.8 & 1.6 & 1.8 & 2.8 \\
\hline Attainment (\%) & 53 & 75 & 96 & 57 & 78 & 92 & 53 & 61 & 92 \\
\hline
\end{tabular}

Pre-cycle activities are done by telling stories using a storybook titled "I can wear my clothes" as an activity that is usually done by teachers, namely telling stories using storybooks. The results of pre-cycle operations are known to be low in children's language skills in being a good listener, participating in a conversation, and being able to perform self-expression as table 1 .

Cycle 1 activities are carried out with four stages of Classroom Action Research, namely 1) planning, by preparing plans for implementing learning, developing puppet media according to the story. The first day the story was titled "My beloved family," the second day was titled "I like to help mom" and on the 3rd day titled "I do not like to fight with my sister" the activity of giving class action was carried out at the morning meeting at circle time. The results of observations are known to be an increase in each indicator, as shown in table 1 . Furthermore, the achievement of actions in cycle one by $53 \%$, as in table 2 . This increase does not meet the target of success. The results of reflexes are known a) there are children who pay less attention during the storytelling process, b) there are children who talk to their friends during the story process so that they interfere with other children, c) there are children who are unable to repeat the story again. This is because wayang cannot stand on their own still dependent on the teacher's movements, so they are less interactive for children to do, the themes in the story are less liked by children, teachers lack expression when telling stories and need sound processing and intonation. Then need improvement in cycle 2. 
TABLE II. RECAPITULATION IMPROVES LANGUAGE SKILLS THROUGH THE METHOD OF STORYTELLING USING PRE-CYCLE WAYANG MEDIA, CYCLE 1, CYCLE II

\begin{tabular}{|c|c|c|c|c|c|c|c|c|c|}
\hline \multirow[b]{2}{*}{ Name } & \multicolumn{3}{|c|}{ Pre-Cycle } & \multicolumn{3}{|c|}{ Cycle- 1} & \multicolumn{3}{|c|}{ Cycle- 2} \\
\hline & $\sum_{\text {Value }}$ & $\begin{array}{l}\text { Passed } \\
\text { Value }\end{array}$ & Note & $\sum_{\text {Value }}$ & Passed Value & Note & $\sum_{\text {Value }}$ & Passed Value & Note \\
\hline Subject 1 & 5 & $56 \%$ & $\mathrm{~F}$ & 7 & $78 \%$ & $\mathrm{P}$ & 9 & $100 \%$ & $\mathrm{P}$ \\
\hline Subject 2 & 5 & $56 \%$ & $\mathrm{~F}$ & 7 & $78 \%$ & $\mathrm{P}$ & 9 & $100 \%$ & $\mathrm{P}$ \\
\hline Subject 3 & 7 & $78 \%$ & $\mathrm{P}$ & 7 & $78 \%$ & $\mathrm{P}$ & 9 & $100 \%$ & $\mathrm{P}$ \\
\hline Subject 4 & 5 & $56 \%$ & $\mathrm{~F}$ & 8 & $78 \%$ & $\mathrm{P}$ & 8 & $89 \%$ & $\mathrm{P}$ \\
\hline Subject 5 & 6 & $67 \%$ & $\mathrm{~F}$ & 8 & $89 \%$ & $\mathrm{P}$ & 8 & $89 \%$ & $\mathrm{P}$ \\
\hline Subject 6 & 3 & $34 \%$ & $\mathrm{~F}$ & 5 & $56 \%$ & $\mathrm{~F}$ & 6 & $66 \%$ & $\mathrm{~F}$ \\
\hline Subject 7 & 5 & $56 \%$ & $\mathrm{~F}$ & 5 & $56 \%$ & $\mathrm{~F}$ & 9 & $100 \%$ & $\mathrm{P}$ \\
\hline Subject 8 & 5 & $56 \%$ & $\mathrm{~F}$ & 7 & $78 \%$ & $\mathrm{P}$ & 9 & $100 \%$ & $\mathrm{P}$ \\
\hline Subject 9 & 5 & $56 \%$ & $\mathrm{~F}$ & 6 & $67 \%$ & $\mathrm{~F}$ & 8 & $89 \%$ & $\mathrm{P}$ \\
\hline Subject 10 & 7 & $78 \%$ & $\mathrm{P}$ & 9 & $100 \%$ & $\mathrm{P}$ & 9 & $100 \%$ & $\mathrm{P}$ \\
\hline Subject 11 & 3 & $34 \%$ & $\mathrm{~F}$ & 5 & $45 \%$ & $\mathrm{~F}$ & 9 & $100 \%$ & $\mathrm{P}$ \\
\hline Subject 12 & 3 & $34 \%$ & $\mathrm{~F}$ & 8 & $89 \%$ & $\mathrm{P}$ & 8 & $89 \%$ & $\mathrm{P}$ \\
\hline Subject 13 & 5 & $56 \%$ & $\mathrm{~F}$ & 5 & $56 \%$ & $\mathrm{~F}$ & 9 & $100 \%$ & $\mathrm{P}$ \\
\hline Subject 14 & 6 & $67 \%$ & $\mathrm{~F}$ & 7 & $78 \%$ & $\mathrm{P}$ & 9 & $100 \%$ & $\mathrm{P}$ \\
\hline Subject 15 & 2 & $45 \%$ & $\mathrm{~F}$ & 4 & $45 \%$ & $\mathrm{~F}$ & 7 & $78 \%$ & $\mathrm{P}$ \\
\hline Subject 16 & 4 & $45 \%$ & $\mathrm{~F}$ & 5 & $56 \%$ & $\mathrm{~F}$ & 6 & $66 \%$ & $\mathrm{~F}$ \\
\hline Subject 17 & 5 & $56 \%$ & $\mathrm{~F}$ & 6 & $67 \%$ & $\mathrm{~F}$ & 9 & $100 \%$ & $\mathrm{P}$ \\
\hline Result & \multicolumn{3}{|c|}{$\begin{array}{c}\text { Percentages Value of Study } \\
\text { Passed } \\
12 \% \text { ( Poor) }\end{array}$} & \multicolumn{3}{|c|}{$\begin{array}{c}\text { Percentages Value of Study } \\
\text { Passed } \\
53 \% \text { ( Good })\end{array}$} & \multicolumn{3}{|c|}{$\begin{array}{c}\text { Percentages Value of Study Passed } \\
88 \% \text { (Very Good) }\end{array}$} \\
\hline
\end{tabular}

From the results of the diagram above shows a significant increase. From pre-cycle, reaching $12 \%$ of 17 children only two children were able to tell a good story, in the first cycle, the percentage of results increased to $53 \%$ of 17 children, only nine children who could tell a story even though it was not valid. In the second cycle, the percentage results increased to $88 \%$ of 17 children; almost all were able to tell stories. So, it can be concluded that storytelling using puppet media can improve children's language skills. This is because the presence of puppet media as a tool for storytelling can help children to visualize the characters in the story so that storytelling activities are more interesting, and children are stimulated to participate in talking.

This is consistent with the results of the study [17] conducted by telling stories using puppets in kindergarten children significantly showed a high level of mediation compared to storytelling without hand puppets. In this study, not using hand puppets but using puppets. According to Vygotsky, children's cognitive and language development is closely related to culture and society where children are raised [7] are one type of traditional puppet in Indonesia. Suyanto added that training children to learn languages can be done by communicating through storytelling, both listening to stories and telling children to tell stories. With learning and exciting media through a game without burdening and depriving them of their childhood [4]. Children's language development will develop with the guidance and assistance of adults so that the child will understand it. Storytelling using the puppet media is entertaining for children so that it can improve children's language skills.
In Figure 1. It can be seen an increase in children's language skills from pre-cycle, cycle 1 and cycle 2 . Then language learning through storytelling with puppets is very effective as learning innovations for young children. Puppet can visualize the characters in the story told by the teacher.

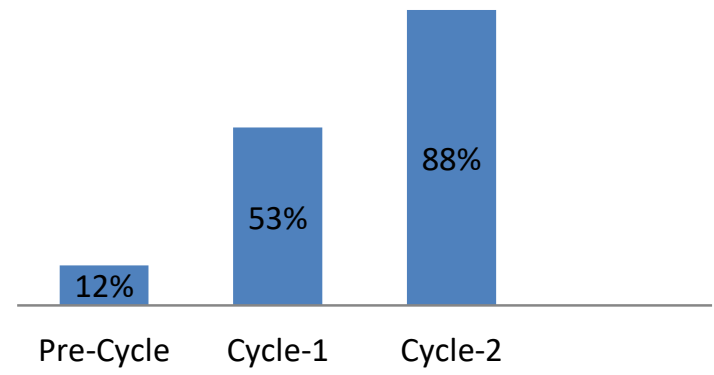

Fig. 1. A diagram of increasing children's language skills

IV. CONCLUSIONS

Based on the results of research that has been done that the application of learning by the method of storytelling does not only use media with picture books, finger puppets, or hand puppets only. But by using the wayang media, which is very interesting, telling stories using puppet media can be done using puppet media in accordance with the theme, after telling the children told to retell the contents of the story using puppet media, children can play the puppet. The puppets used must be exciting and appropriate for the age of the child. Increased language skills through storytelling using puppet media in group $\mathrm{B}$ children with the percentage results in the observation of pre-cycle language skills activities by $12 \%$, 
but after the action cycle, I became increased by $53 \%$. Then the researchers went on to give action on the second cycle using the puppet media, which is very interesting for children, increasing by $88 \%$. The results of the study were declared successful and were following the research target.

\section{REFERENCES}

[1] W. Crain, Teori Perkembangan Konsep dan Aplikasi alih bahasa Yudi Santoso. Yogyakarta: Pustaka Pelajar, 2007.

[2] N. Fridani, Lara; Dhieni, "Hakikat Perkembangan Bahasa Anak," Metod. Pengemb. Bhs., 2014.

[3] R. Hildayani and et.al, Psikologi Perkembangan Anak. Jakarta: Universitas Terbuka, 2014.

[4] A. Susanto, Perkembangan Anak Usia Dini. Jakarta: Bumi Aksara, 2011.

[5] W. Gunarti and et.al, Metode Pengembangan Perilaku dan Kemampuan Dasar Anak Usia Dini. Tangerang Selatan: Universitas Terbuka, 2015

[6] B. A. Wasik and J. L. Jacobi-Vessels, "Word Play: Scaffolding Language Development Through Child-Directed Play," Early Child. Educ. J., vol. 45, pp. 769-776, 2017, [Online]. Available: https://link.springer.com/article/10.1007/s10643-016-0827-5.

[7] N. Dhieni et.al, Metode Perkembangan Bahasa. Jakarta: Universitas Terbuka, 2015.

[8] H. Geisler, Storytelling Professionally: The Nuts and Bolts of a Working Performes. Englewood Colorado: Libraries Unlimited, Inc, 1997.
[9] E. P. Quintero, "Something to say: Children learning through story," Early Educ. Dev., 2010, doi: $10.1080 / 10409280903440612$

[10] D. Kleeman, "Media exposure during infancy and early childhood: the effects of content and context on learning and development," J. Child. Media, vol. 11, pp. 504-506, 2017, doi: 10.1080/17482798.2017.1375219.

[11] A. K. Diergarten, T. Möckel, G. Nieding, and P. Ohler, "The impact of media literacy on children's learning from films and hypermedia," J. Appl. Dev. Psychol., vol. 48, pp. 33-41, 2017, doi: 10.1016/j.appdev.2016.11.007.

[12] A. Daboti and M. Agustin, "Efektifitas Penggunaan Metode Bercerita Dengan Menggunakan Media Audio Visual (Wayang) Terhadap Tingkat Disiplin Anak Usia Dini," Edusentris, vol. 5, no. 1, p. 35, 2019, doi: 10.17509/edusentris.v5i1.292.

[13] R. Moeslichatoen, Metode Pengajaran di Taman Kanak-kanak. Jakarta: PT. Rineka Cipta, 1999.

[14] S. Arikunto, "Prosedur Penelitian Tindakan Kelas," Bumi Aksara, 2006.

[15] S. Kemmis and R. McTaggart, The action research planner. Victoria: Deakin University, 1999.

[16] A. Sudijono, Pengantar Statistik Pendidikan, 27th, 2018th ed. Jakarta: Raja Grafindo persada, 2018.

[17] D. Tzuriel and R. Remer, "Mediation with a puppet: The effects on teachers' mediated learning strategies with children in special education and regular kindergartens," Learn. Instr., vol. 58, pp. 295-304, 2018, doi: https://doi.org/10.1016/j.learninstruc.2018.08.001. 